\title{
HUMAN RIGHTS BASED LAW ENFORCEMENT FOR THE VIOLATION OF LOCAL REGULATION BY CIVIL SERVICE POLICE OF SEMARANG MUNICIPALITY
}

\author{
Joko Setiyono \\ Faculty of Law Diponegoro University Semarang, Indonesia \\ jokosetiyono61@yahoo.com
}

\begin{abstract}
In the era of regional autonomy, the role of civil service police in the enforcement of Local Regulations is crucial to support regional development. However in practice, civil service police often find obstacles and resistance from the public they face. Therefore, it is required for civil service police to act on the base of human rights during the regulation enforcement process. The results hows that the performance of Semarang civil service police in conducting the Local Regulations enforcement process during 2009-2014 had been done based on human rights. There are still any resistance from the public in some actions, but it can be understood as the result of lack of socialization about the regulations, lack of dialogue and coordination with the citizens, as well as lack of satisfaction of citizens in the solution or redress given to them.
\end{abstract}

Keywords : human rights, enforcement, violation, local regulation, municipality

\section{Introduction}

\subsection{Background}

In the era of regional autonomy, not only the Civil Service Police (Satpol $\mathrm{PP}^{81}$ ) has a more significant role, but they also becomes a strategic part of local government institution in which their duties are to help out and to enforce Local Regulations and to maintain public order and security. The reform era improves the democratic life, however it also encourage people's behavior and social changes which sometimes intersect with public order and security issues under the authority and duties of civil service police.

81 Satpol PP are local law/regulation enforcement agencies which work under the control of local government in Indonesia and they receive funding from the local government budget. 
Enforcement against violations of Local Regulations usually intersects with the interests of the marginalized class. Many community activities may contain various kinds of abuses, which ironically for them, are not perceived as a form of offense, although there are already some rules that govern them. The reason is that those people may never get the information or warning from the authorities about the ban in the Local Regulation.

The law enforcement officials generally act decisively after the violation has been accumulated, so it makes the law enforcement process requires more efforts, high cost and also deep thinking. Not infrequently that the law enforcement process was repressively and arrogantly implemented by the civil service police.

Today the roles of civil service police are no longer to be limited to punitive regulatory tasks, such as displacing or conducting raids on various social issues which are considered in violation of Local Regulations. Civil service police need to carry out a review of their roles with a more contextual ones. Criticality and awareness of community to obtain their rights to viable public services and guaranteed order, demanding civil service police not only to be professional, but also to be consistent and fair. They must not hurt the sense of justice of the marginalized class and in running their vital duty they must not violate the universal principle of human rights.

However the real condition shows some of weaknesses that civil service police still have, such as the human resources, the availability of facilities and infrastructures, and the available budget. In terms of human resources, there are still a lot of personnels or members who have not attend the course and basic training yet. The available data shows that only $27 \%$ of 32.188 members of the civil service police have status as Civil Servants who has attended and graduated in education and basic training, while the civil service police with non Civil Servant status who have attended the course and basic training are 53. 34\% of the total number of 35,987 members.

Because of a variety of the problems that plagued the civil service police, in keeping the existence of this unit, they must no longer rely on the repressive 
approaches, but also rely on the sensitivity to understand the various social problems, to empathy, and to be able to garner support from any social institutions in order to prevent human rights violations.

To live within of society, nation or state, a man has the obligation to carry out the law. It is associated with the notion of law as a set of instructions (commandments and prohibitions), which regulates the order in a society. This understanding shows that the law aims for creating security and peace within a society. The high role of law in regulating public life makes it as a reference in the application of rule of law. In the state governance, law holds a crucial role in ensuring the fair administration of the state. Justice is a measure in determining the agreement on truth and error prevailing in the society in a country. Law has a full power to regulate the application of justice in the state governance. ${ }^{82}$

The essence of respect and protection of human rights is to maintain the safety of human existence as a whole through the action of balance, ie the balance between rights and obligations, as well as the balance between the interests of individuals and common interests. Fulfillment, protection and respect for human rights therefore must be followed by the fulfillment of the obligation on Human Rights and Human Responsibilities in a personal, society and state life. Thus when the three fundamental elements comprising human rights, human obligation, and responsibility for human rights does not run balanced, it will certainly lead to chaos, anarchy and arbitrariness.

A member of Satpol PP is essentially a police officer, a part of law enforcement officials (law enforcer). In accordance with the provisions of Article 138 of Law Number 32 of 2004 on Regional Government, Satpol PP was formed with one of their jobs is to assist the Regional Head in establishing local Regulations. As known, the Local Regulation in accordance with the provisions of Article 7 paragraph (1) of Law Number 10 of 2004 on the Establishment

82 Ahmad Fadlil Sumadi, Jurnal Konstitusi, Volume 12, Nomor 4, Desember 2015, Hukum dan Keadilan Sosial dalam Perspektif Hukum Ketatanegaraan, p. 849-871 
Regulation Legislation is one kind of legislation that serves as a positive law in the state system in the Republic of Indonesia.

In chapter I on general provisions, Minister of Home Affairs Regulation No. 38 of 2010 states clearly that the definition of civil service police is part of the institution in the area of enforcement of Local Regulation, implementation of public order and public peace. While Polisi Pamong Praja are civil service police members which act as local government officials in the enforcement of Local Regulation, implementation of public order and public peace and protection of the community. Furthermore, in the Minister of Home Affairs Number 38 of 2010, it has been confirmed too that the intended public order and peace of society is a dynamic state which allows the Central Government, Local Government, and the public to conduct their activities safely and orderly.

Organization made up of individuals and groups, and therefore the effectiveness of the organization is critically affected by both individual and group effectiveness. However the effectiveness of the organization is more than just the sum of the effectiveness of individuals and groups. Through synergy, organizations gain a higher level of effectiveness than the sum of the part. ${ }^{83}$ For Satpol PP as a part of law enforcement officials, their respect for human rights in the line of duty should always be embedded in the hearts, so that human rights violations will be reduced to a minimum.

Based on that rationale, it is necessary to do research on "Human Rights based Law Enforcement for the Violation of Local Regulation by Civil Service Police (Satpol PP) of Semarang Municipality" with the formulation of problem as follows:

a. Why should the law enforcement for violations of Local Regulations by the civil service police be based on Human Rights?

b. Does the law enforcement for violations of Local Regulations by the civil

83 Gibson dalam Amir Syarifudin Kiwang, David B.W.Pandie, dan Frans Gan, Jurnal Kebijakan Publik, Volume 5, Nomor 1, Maret 2014, Kebijakan Publik dan Efektivitas Organisasi, p. 90101 
service police police of Semarang municipality has been done based on Human Rights?

\section{Research Methods}

This study uses juridical normative approach by relying on the provisions of the normative ${ }^{84}$ legal rules which are related to the subject matter in a study entitled "Human Rights based Law Enforcement for the Violation of Local Regulation by Civil Service Police of Semarang Municipality". This study uses descriptive analysis method, in which the analysis critically conducted to the subject of research, by using literature and documentary study and also field research related to the main substance of the study. After the data have been collected, the next process is to identify, to clarify, and to analyze systematically; and finally all the research results is presented in a compiled final report.

\section{Result and Discussion}

\subsection{Human Rights Based Law Enforcement for Violations of Local Regulation by Civil Service Police}

The enforcement of Local Regulation with regards to public order and peace in people's lives intersects with the interests of middle to low class, particularly the marginalized one. In reality, there are some public activities which contain various forms of violations of applicable laws and regulations, including Local Regulations.

Ironically in this case, the perpetrators of the offense itself, both citizens and legal entities did not recognize it as a violation, even if the there are any existing laws and regulations that govern them. One likely cause is that people may never got the information and dissemination from the authorities regarding the prohibition contained in a Regional Regulation and may never have been involved in the manufacturing process Regional Regulation meant.

84 Ronny Hanitijo Soemitro, Metodologi Penelitian Hukum Dan Yurimetri, Ghalia Indonesia, Jakarta, 1990, p 10 
Existence of a civil service police who constantly work required in the administration of local government, juridical normative has been stated in the provisions of Article 148 of Law No. 32 of 2004 which states that in order to assist the Regional Head in establishing the Regional Regulation and the implementation of public order and peace in the society then the civil service police is needed.

The first path can be done through institutional cooperation together with other relevant government agencies. The second path can be done through community empowerment, namely by encouraging public performance, in which community or religious leaders may report all forms of violation of Local Regulation.

In accordance with the provisions of the applicable laws, regulations enforcement activities by the civil service police can be done gradually. The first stage is a pre-emptive action, by which the civil service police can disseminate and do any persuasive actions to the public and relevant agencies so that Local Regulations will be enforced by the community complied with awareness and responsibility. Furthermore, in the second stage, any actions are taken preventively. In this case, the civil service police can carry out their regular activities by conducting patrols and surveillance in order to prevent any breach of the Local Regulation.

Moreover, it can also be done with a strike either orally or in writing to the parties that have violated Local Regulation, in order to comply with the Regional Regulation and to try in full awareness not to violate again later. Lastly the third stage, civil service police can carry out repressive actions, where in this case there has been un-tolerated violations of the Local Regulation. Violators will be dealt with strictly, both judicial and non judicial action by Satpol PP with involvement of other law enforcement agencies.

At this point, to complement the effectiveness of regulations enforcement, civil service police needs human rights-based approach. With this approach, it is needed to build the capacity of persons in claiming their rights and ability of duty bearers to fulfill their obligations through policy analysis, advocacy, capacity 
building, and to help facilitate the process of empowerment of the poor and marginalized. In the end, human rights-based approach aims to create a condition in which everyone can live in dignity and peace to fully develop his/her assets, potential and abilities. ${ }^{85}$ However, the governments also need to understand that unlike the 'necessity', which are contextual and subjective, human rights requires an existence of responsible party. Therefore, if a state fails to perform its obligations to fulfill the economic, social, cultural rights then any person who had knocked out has a reason to fight against. ${ }^{86}$

If this human rights based approach is integrated in the system of regional autonomy then there would be constitutionally guarantees and protection, although it does not mean that human rights will certainly be respected. Constitution guarantee level is merely the norm stipulating that human rights are exist, recognized and protected. Meanwhile, its implementation depends on the availability of institutional infrastructure, mechanisms and commitment of the government. $^{87}$

\subsection{A Dilemma of Civil Service Police}

An effective regional regulations but never socialized properly by the Local Government or any related agencies will reduce the public's understanding of the importance of the Regulation so that efforts to enforce the local Regulation does not give the impression of justice for all people. No wonder in the law enforcement process for the local regional, the civil service police and Civil Servant Investigators often act repressively and arrogantly.

For example, the civil service police action which is considered very negative by the community is the death of a 4.5 years old toddler due to doused by hot sauce meatballs in the control operation of street vendors in Surabaya. Another example is the control operation of the women prostitutes in Jakarta, which also led to the

85 Mimin Dwi Hartono, Komisi Yudisial: Jurnal HAM Vol. 8 Tahun 2012, Pendekatan Berbasis HAM dalam Penanganan Bencana: kasus erupsi gunung Merapi, p. 133-166

86 Stanley Adi Prasetyo, Komisi Yudisial: Jurnal HAM Vol. 8 Tahun 2012, Pemberian Jaminan Sosial dalam Hak Asasi Manusia , p.249-264

87 Saldi Isra, Jurnal Konstitusi, Volume 11, Nomor 3, September 2014, Peran Mahkamah Konstitusi dalam Penguatan Hak Asasi Manusia Di Indonesia, p.409-427 
death of a prostitute who drowned in the river to evade civil service police officers. However in the final report of this study, only a few examples of sympathetic actions of members of civil service police in performing their duties and functions in the field in accordance with the legal provisions and regulations and protection of human rights will be presented.

Table 1. Some Sympathtic Actions PP Civil Service Police in Several Cities in Indonesia

\begin{tabular}{|c|c|}
\hline City & Action \\
\hline Pekalongan & $\begin{array}{l}\text { Pekalongan civil service police are constantly deployed to assist } \\
\text { the Pos PAM Lebaran in the several critical locations in their } \\
\text { working area including at the crossing of Railways and public } \\
\text { facilities } \\
\text { Working together with a joint team of the Election Supervisory } \\
\text { Committee in removing hundreds of props or campaign attributes }\end{array}$ \\
\hline Mojokerto & $\begin{array}{l}\text { Monitoring of cleanliness, beauty and leisure (K3) in the Brantas } \\
\text { River } \\
\text { Raids against illegal buildings on the banks of the River Porong, } \\
\text { Ngame Village }\end{array}$ \\
\hline Tuban & $\begin{array}{l}\text { Supervision for repatriation of prostitutes and the closure of } \\
\text { Wonorejo localization } \\
\text { Patrol and survey of illegal buildings in the District Jenu, Tuban }\end{array}$ \\
\hline Surabaya & $\begin{array}{l}\text { Handling of demonstrations are conducted in an orderly, peaceful } \\
\text { and sympathetic action without causing physical clash and } \\
\text { destruction of public and social facilities have also been } \\
\text { implemented by the civil service police for the Federation of Trade } \\
\text { Unions Cigarettes, Tobacco, Food and Beverages } \\
\text { Oversight in delivery of social assistance and repatriation of ex- } \\
\text { prostitutes Tambak Asri Surabaya } \\
\text { Guard protests about public rejection in the increase of fuel prices }\end{array}$ \\
\hline Sidoarjo & $\begin{array}{l}\text { Illegal buildings in the District of Letjen Sutoyo Waru, Sidoarjo } \\
\text { regency are curbed } \\
\text { Illegal buildings on Stren Kalimas in Keramat Temegung village, } \\
\text { District of Tarik are curbed }\end{array}$ \\
\hline
\end{tabular}

The previous examples show some actions of civil service police actions who able to develop sympathetic approach to achieve the objectives without violating human rights. On handling of social conflicts, the authorities should not 
discriminate in service or only act as individual intellectual that are not grounded in society, but they should be sensitive to community in solving the problems in their environment. $^{88}$

A strong influence of the news have provided an overview on all the people of Indonesia, that the civil service police is one of the institutions within the scope of central government and regional public attention not because of the achievements of achievement performance in maintaining peace and public order, but often commit acts of violence in humanity beyond the limits that are considered to violate human rights in carrying out the duties and functions noble accordance with the laws and regulations.

In addition, sometimes the civil service police has also been considered to be a threat that is very frightening to people who are marginalized, as well as street vendors, beggars and other street children who work as beggars and prostitutes. This perception, if not addressed and resolved out wisely and prudently, can be a serious threat to the Unitary Republic of Indonesia through the separatist movement and anarchism, including terrorism.

Today people have a critical awareness of their rights to obtain public viable services, causing the Local Government including all his staff and the civil service police to act professionally, and trying hard not to hurt the public sense of justice by promoting respect for human dignity as human rights are universal.

For Indonesian, strong or weak enforcement by the authorities would determine public perception of law. When enforcement by the authorities is weak, public will perceive law as nothing, and as if they were in the jungle. Conversely if enforcement by the authorities are strong and it is carried out consistently, then public will perceive that there is law and they will obey it. In such a context of Indonesian society still in the stage of society "scared" at the (enforcement of) law and can't be categorized as people who "obey" the law. In societies that fear of law, public will not be subject to the law if law enforcement is weak, inconsistent, and

88 Suparmin, Jurnal Masalah-Masalah Hukum Jilid 43 No. 2 April 2014, Reorientasi Peran Polri dalam Penanganan Konflik Sosial dari Perspektif Penegakan Hukum, p.224-232 
unreliable. Therefore, strict law enforcement and authoritative in the legal life of Indonesian society is really needed. ${ }^{89}$

Even so, according to human rights activists, such conditions confirms that whatever the pretext of Local Government in general and in particular civil service police can't cover the occurrence of a state of violence on citizens. On the other hand according to M. Irsyat Thamrin (2009) in his article "civil service police: enforcing the law without rule of law", states that law enforcement officials are authorized to carry out acts of violence in enforcing Local Regulation, however it is not a pretext to justify and legalize acts of violence that have been included in the category of crime.

As a guard against Local Regulation will certainly make members of civil service police are often in a dilemma, on the one hand doing the enforcement of Local Regulation in order to avoid public disorder (social disorder), but on the other hand is often a clash with the public. In making the arrangement to the vendors, conduct raids on commercial sex workers, street children, vagrants and beggars in the name of beauty and cleanliness of the city, making civil service police sometimes have to clash with the poor, marginalized people who are looking for a bite of rice at the edge of the road.

\subsection{Some Obstacles of Human Rights Based on Law Enforcement}

With some internal constraints such as availability of funding and a limited number of personnel, it is clearly impossible for Satpol PP to work alone to enforce Local Regulation, in which both citizens and legal entities which are subject to the law which have rights and the same obligations, to maintain social order and public tranquility. Such conditions make the civil service police work hard to gain public sympathy and support for the smooth implementation of their duties and functions.

Thus, it is logical that civil service police took part in the effort to prevent interference public order and peace through humanist approach by promoting respect and protection of human rights. Furthermore, to avoid disruption of the

89 Imron Rosyadi, Jurnal Sains dan Inovasi III(2)2007, Penegakan Hukum Dalam Masyarakat Indonesia, p.77-82. 
public order and peace, then ideally civil service police should pay attention to the following matters:

a. Any conditions that could lead to social inequalities (social gap) to minimize opportunities for marginalized communities absorbed in industrial activity and development. When Social gap get less attention, it may cause a variety of social problems, therefore the civil service police should be able to anticipate, so that the public order and peace in the society still can be maintained;

b. In the event that the value of a legal basis covering usability, certainty and fairness are no longer perceived justice seekers. Law impartially and offend the sense of justice, implicated in the occurrence of various rallies or demonstrations, and resistance leading to anarchic actions that cause disruption of order, peace and public security;

c. The conditions in which functional communication forum to neutralize the differences that exist are not well developed or likely to be covered up, so the role of civil service police in order to prevent the occurrence of open friction becomes very important. Social conditions as mentioned above can't be allowed, because it would be impossible to not disturb public order and peace, as well as destabilizing national unity.

The right strategy for civil service police to prevent and anticipate the possibility of a disruption to public order and tranquility is by developing a mechanism for early detection and humanist approach by prioritizing the protection and respect for human rights and empower people in all aspects of their life.

Furthermore, some major issues that must be considered by the civil service police in order to maintain favorable conditions are the potential horizontal conflict related to local elections, election of Members of the Legislative, and the Presidential Elections, which can disturb public order and public tranquility. Besides issues related to corruption, collusion and nepotism, labor, and land evictions often triggers rallies and mass resistance, all of which would require a wise and prudent attitude of the civil service police in maintaining public order and peace. 
Other issues that also must be considered by the civil service police is the number of regional regulations, while in the field there is a tendency of society and the legal entity as a legal subject, which is always looking for loopholes in the law to break. Other key issues related to the increasing number of threats which may harm public order and public tranquility and may cause the decline of social control and social environmental awareness, a serious concern of civil service police in performing their duties and functions.

The civil service police efforts to maintain public order and tranquility are influenced by internal and external factors. Internal factors, at least can be identified with regard to their limited number of members, budget, facilities and infrastructure to support the duties and functions of civil service police in the field. These factors may have implications for the smooth implementation of the tasks in the enforcement of Local Regulation, maintaining public order and peace by the civil service police. Those internal factors include the problems faced by civil service police with a low welfare and a lack of guarantee for their safety while on duty.

While external factors, especially associated with less effective socialization of the existence of a local Regulation, as well as low levels of education, legal awareness, and socioeconomic conditions of marginalized communities. Those conditions certainly have some impacts for civil service police in performing their duties and functions, which sometimes threaten their lives. Another external factor in the efforts to enforce the Regional Regulations and efforts to create public order and tranquility is technical problems of coordination between relevant agencies that have not run optimally.

Other external factors are the supervision of the public. Supervision in implementation of public services, either directly or indirectly will encourage community participation in order to prevent the occurrence of irregularities, so that clean government which are free from corruption, collusion and nepotism (KKN) can be realized. And this will certainly also affecting public service that does not deviate from the noble objectives for the welfare of all the people of Indonesia. 
This stage is very urgent so that the elements of good governance, especially the principles of accountability, transparency, excellent service, democracy and the rule of law can be implemented. ${ }^{90}$

In addition, the openness of the legal and political arena in Indonesia for human rights discourse is not followed by a real impact on people's position. The problem of weak institutions and enforcement are less enthusiastic indicates that in Indonesia, human rights formally adopted as a political strategy to avoid the substance implementation. ${ }^{91}$ Respect for human rights shall be kept in mind by every member of the civil service police in performing basic tasks and its function in the field. The image that less favorable to the civil service police in performing their duties and functions in the field, primarily related to the enforcement of Local Regulation, at least caused by five main factors as follows: eviction by force, mistreatment against marginalized communities, brutal treatment accompanied by beatings, antipathy by marginalized people, and arrogant and inhumane.

The demands for a better performance of the apparatus and professionals from the government seems inevitable, especially after the regional autonomy. Without a good performance and transparency of the apparatus, any positive progress will be difficult to achieve. Furthermore, to build a positive image and to get support from all people, Satpol PP in performing their duties and functions related to Local Regulation enforcement may consider some basic things, namely: External reform: early socialization to educational institutions, lesson giver by the unit leader, leaving the culture of violence in carrying out its duties and functions, mindset change of leaders and members in the enforcement of regulations, and changes from physical approach towards humanitarian approach.

\subsection{Human Rights based Law Enforcement for the Violations of Local Regulation by Civil Service Police of Semarang Municipality}

\footnotetext{
90 Nuriyanto, KPK: Jurnal Integritas Vol. 1, November 2015, Membangun Budaya Hukum Pelayanan Publik untuk Mewujudkan Kesejahteraan Masyarakat, hlm. 15-36.

91 Irene Istiningsih Hadiprayitno, Hum Rights Rev (2010) 11, Defensive Enforcement: Human Rights in Indonesia, hlm. 373-399.
} 
Semarang municipality has an area of $373.70 \mathrm{~km}^{2}$, which is administratively divided into 16 sub districts and 177 villages. Population of Semarang municipality in 2012 was 1,559,198 inhabitants with population growth during 2012 amounted to $0.96 \%$.

The main source to find out the the performance of Satpol PP of Semarang municipality in conducting enforcement against Local Regulation violations the website suaramerdeka.com that have been posted for five (5) years, starting from 2009 to 2014.

Table 4 List of News about Satpol PP of Semarang Municipality In 2009-2014

\begin{tabular}{|c|c|}
\hline Date & Headline \\
\hline 15-Jan-2009 & Transverse, banners of legislative candidates removed \\
\hline $5-F e b-2009$ & Chaotic demolition of goatfold \\
\hline 7-Mar-2009 & Protrudes, Poncol station kiosks are demolished \\
\hline 16 April 2009 & A total of 3.6 quintals of gelonggongan meat secured \\
\hline 14-May-2009 & Keep an eye on street vendors, PP satpol PP guard apparel \\
\hline 23-Jun-2009 & Siyem cigarett, clarification of excise label \\
\hline 10-Jul-2009 & A week of operation, massage parlors are closed \\
\hline 21-Aug-2009 & Satpol PP raid on massage parlors in Semarang \\
\hline 29-Aug-2009 & Semarang is flooded with beggars dropped from out of town \\
\hline 26-Sep-2009 & $\begin{array}{l}\text { Exceeding the time limit selling, street vendors are } \\
\text { disciplined }\end{array}$ \\
\hline 24-Oct-2009 & Void satpol PP evicted street vendors of progo \\
\hline 24-Nov-2009 & Again, Satpol PP curb street vendors \\
\hline 1-Dec-2009 & Demolition of illegal street stalls in Kaligawe ends chaotic \\
\hline 14-Jan-2010 & $\begin{array}{l}\text { Satpol PP asked to immediately curb the street vendors at } \\
\text { Kartini }\end{array}$ \\
\hline 27-Jan-2010 & TPS garaha Padma not be dismantled \\
\hline 16-Feb-2010 & Street vendors still active, workers make a fence of bamboo \\
\hline
\end{tabular}




\begin{tabular}{|c|c|}
\hline 13-Mar-2010 & Demolition PKL Sampangan ends chaotic \\
\hline 17-Mar-2010 & Street vendors at Sampangan established a center \\
\hline 27-May-2010 & Satpol PP catch dozens of civil servants \\
\hline 9-Jun-2010 & A total of $65 \mathrm{~kg}$ of illegal meat is secured \\
\hline 6-Jul-2010 & Unloading street vendor kiosk as coordinated by satpol PP \\
\hline 21-Jul-2010 & PP satpol raid makes beggars in revolt \\
\hline 29-Aug-2010 & Arbitrarily stop cars are expelled \\
\hline 29-Sep-2010 & Satpol PP raid for illegal parking in the city of Semarang \\
\hline 30-Sep-2010 & Occupants of illegal buildings unloading plots voluntarily \\
\hline $8-O c t-2010$ & $\begin{array}{l}\text { Eating in a warung, his/her motor is transported by Satpol } \\
\text { PP }\end{array}$ \\
\hline 20-Oct-2010 & Buildings on the tract are demolished \\
\hline 4-Nov-2010 & Street vendors at Pahlawan are temporarily relocated \\
\hline 24-Nov-2010 & Jukir make chaotic parking system \\
\hline 3-Dec-2010 & Parking on the Pandanaran street in force close \\
\hline 27-Dec-2010 & Two karaoke forcibly closed \\
\hline 31-Jan-2011 & Simpang Lima is free from peddlers \\
\hline 13-Feb-2011 & Demolished house owner reports to the police \\
\hline 11-Feb-2011 & Miners are reckless to operate \\
\hline 13-Feb-2011 & Satpol PP closed excavation type C Mangunharjo \\
\hline 15-Mar-2011 & Satpol PP seize Beghoe key \\
\hline 11-Mar-2011 & A total of 17 prostitutes are secured \\
\hline 2 April 2011 & Dozens of street vendors huts at Kaligawe are dismantled \\
\hline 5 April 2011 & Careless litter send to trial \\
\hline 26-May-2011 & Satpol PP curb florists at Pandanaran street \\
\hline 27-May-2011 & Satpol PP dismantle vendor streets lapak at kokrosono \\
\hline 21-Jun-2011 & Satpol PP curb traders again \\
\hline 22-Jun-2011 & $\begin{array}{l}\text { Buildings at Barito are demolished, residents protests the } \\
\text { head of the village }\end{array}$ \\
\hline
\end{tabular}




\begin{tabular}{|c|c|}
\hline 15-Jul-2011 & Demolition of took material fence are protested \\
\hline 9-Sep-2011 & Ramadan and Eid, 46 PGOT are arrested \\
\hline 11-Sep-2011 & the street vendors needs environmental safety \\
\hline 14-Sep-2011 & $\begin{array}{l}\text { Three main street in Semarang are curbed from streed } \\
\text { vendors }\end{array}$ \\
\hline 12-Oct-2011 & Eight karaoke illegal buildings are demolished \\
\hline 26-Oct-2011 & Illegal buildings on the river bank of Semarang are curbed \\
\hline 7-Nov-2011 & Violating K3, 12 kiosks at Taman $\mathrm{KB}$ are sealed \\
\hline 24-Nov-2011 & Kiosk next to the park of UNNES kelud are sealed \\
\hline 29-Dec-2011 & Karaoke near MAJT are failed to torn down \\
\hline 30-Jan-2012 & Relaxing at the mall, 4 Civil Servants (PNS) are disciplined \\
\hline 14-Feb-2012 & Satpol PP didn't come, pasindra traders chose silence \\
\hline 18 Pebuari 2012 & Traders fight against, sealing fails \\
\hline 1-Mar-2012 & $\begin{array}{l}\text { Satpol PP was slow in operation, } C \text { type mining at } \\
\text { Mangunharjo reoperates }\end{array}$ \\
\hline 7-Mar-2012 & C type mining will be simultaneously sealed by satpol PP \\
\hline 8-Mar-2012 & Four closed mining remains operating \\
\hline 17 April 2012 & $\begin{array}{l}\text { availability of place as an obstacle in controlling street } \\
\text { vendors in Semarang }\end{array}$ \\
\hline 19 April 2012 & $\begin{array}{l}\text { street vendors at thamrin are restless, received warning letter } \\
\text { from the government }\end{array}$ \\
\hline 9-May-2012 & Videotron sealing ends chaotic \\
\hline 26-Jun-2012 & $\begin{array}{l}\text { Newsstand at RPU Penggaron are raffled, firmness is needed } \\
\text { services market }\end{array}$ \\
\hline 27-Jun-2012 & The raffle stall RPU fail, traders are reluctant to submit stall \\
\hline 18-Jul-2012 & Dozens of illegal karaoke near MAJT are dismantled \\
\hline 19-Jul-2012 & Karaoke is often used for prostitution \\
\hline 22-Aug-2012 & Sprawl spread in Semarang \\
\hline 25-Aug-2012 & Skates rental providers expelled \\
\hline
\end{tabular}




\begin{tabular}{|c|c|}
\hline 28-Sep-2012 & $\begin{array}{l}\text { BBWS ask the PP satpol PP for unloading homes Ngemplak } \\
\text { Simongan }\end{array}$ \\
\hline 4-Oct-2012 & Many billboards bulging in the area of Simpang Lima \\
\hline 12-Nov-2016 & Illegal Karaoke grows, satpol PP still selective in handling \\
\hline 13-Dec-2012 & Protrudes into the shoulder of the road, buildings leveled \\
\hline 17-Dec-2012 & Turned into a shop, 12 stalls of street vendors demolished \\
\hline 28-Dec-2012 & Dozens of satpol PP secured PGOT \\
\hline 8-Jan-2013 & $\begin{array}{l}\text { Kiosk of goat and street stalls at Tentara Pelajar are } \\
\text { demolished }\end{array}$ \\
\hline 15-Jan-2013 & $\begin{array}{l}\text { Satpol PP dismantle } 80 \text { street vendor temporary kiosks at } \\
\text { Kaligawe }\end{array}$ \\
\hline $13-F e b-2013$ & A total of 40 signs will be installed tricycles \\
\hline 20-Feb-2013 & $\begin{array}{l}\text { Disciplined PP satpol PP, street vendors and rickshaw are } \\
\text { disappointed }\end{array}$ \\
\hline 28-Feb-2013 & Satpol PP decamp street vendors kiosk permanently \\
\hline 6-Mar-2013 & $\begin{array}{l}\text { Disturb pedestrians, street vendors are dismantled by Satpol } \\
\text { PP }\end{array}$ \\
\hline 8-Mar-2013 & PP satpol PP sealed the game Arena \\
\hline 12 April 2013 & A total of 300 illegal karaoke still operating \\
\hline 1-May-2013 & Controlled by Satpol PP, street vendors fight against \\
\hline 4-Jun-2013 & Satpol PP clears the main street from street vendor \\
\hline 26-Jun-2013 & $\begin{array}{l}\text { Stubborn street vendors at Simpang Lima are dismantled } \\
\text { again }\end{array}$ \\
\hline 26-Jul-2013 & $\begin{array}{l}\text { Face eviction, residents of Bongsari Semarang complained } \\
\text { to council }\end{array}$ \\
\hline 24-Sep-2013 & Deliksari housing project is sealed by Satpol PP \\
\hline 8-Oct-2013 & Handling of street children is a priorities of Satpol PP \\
\hline 22-Oct-2013 & $\begin{array}{l}\text { Satpol PP threatened to remove illegal buildings at Unta } \\
\text { road }\end{array}$ \\
\hline
\end{tabular}




\begin{tabular}{|c|c|}
\hline 6-Nov-2013 & Unlicensed tower on the Medoho road is dismantled \\
\hline 21-Nov-2013 & $\begin{array}{l}\text { Nasty internet cafe is booming, Satpol PP threatened for } \\
\text { sealing }\end{array}$ \\
\hline 20-Dec-2013 & Dozens of illegal karaoke buildings are sealed by Satpol PP \\
\hline 27-Dec-2013 & $\begin{array}{l}\text { Demolished dozens of illegal street vendors abandoned } \\
\text { hospital Semarang }\end{array}$ \\
\hline 14-Jan-2016 & Satpol PP watched the street vendor of Agus Salim \\
\hline 15-Jan-2014 & the anti-political trash movement is booming \\
\hline 28-Feb-2014 & Satpol PP dismantle illegal buildings \\
\hline 17-Mar-2014 & $\begin{array}{l}\text { in order to maximize the role of satpol PP in securing the } \\
\text { election }\end{array}$ \\
\hline 12-Jun-2014 & Illegal karaoke buildings are torn down \\
\hline 5-Jul-2013 & $\begin{array}{l}\text { DI raid violated two karaoke bars open during the hours of } \\
\text { fasting }\end{array}$ \\
\hline 11-Jul-2013 & Street vendor selling fireworks at johar are laid \\
\hline
\end{tabular}

Analysis of the data related to Satpol PP of Semarang municipality during 2009-2014 shows that some of the actions and operations cause a rejection from the public they face. This may be caused by a lack of socialization on the regulations, a lack of dialogue and coordination to the citizens, or maybe the solution or the compensation offered by the government was rejected by the community. In general, most Satpol PP actions have been done in accordance to the existing regulations. However their technical implementations still cause some resistance from the community, so they need any approaches which are more sympathetic and persuasive to ensure that any future operations can be run smoothly, to gain some support from the community, and also to increase the public trust.

\section{Conclusion}

The process of human rights based enforcement of Local Regulation by Satpol PP may be started from the use of standard operating procedures which 
include the preemptive, preventive, and repressive stages. The use of humanist approach, by focusing on the performance of persuasive action rather than physical strength, is an appropriate strategy for satpol PP, especially in handling the marginalized class;

Based on the articles from Suara Merdeka newspaper about the performance of Satpol PP in Semarang municipality during 2009-2014, it can be concluded that generally they has acted in accordance to Human Rights. Although there are any resistance from the public in some actions, it still can be understood as the result of lack of socialization about the regulations, lack of dialogue and coordination with the citizens, as well as lack of satisfaction of citizens in the solution or redress given to them.

\section{References}

Ahmad Fadlil Sumadi. (2015). Hukum dan Keadilan Sosial dalam Perspektif Hukum Ketatanegaraan. Jurnal Konstitusi, 12(4).

Gibson dalam Amir Syarifudin Kiwang, David B.W.Pandie, dan Frans Gan (2014). Kebijakan Publik dan Efektivitas Organisasi. Jurnal Kebijakan Publik, 5(1).

Imron Rosyadi. (2007). Penegakan Hukum Dalam Masyarakat Indonesia. Jurnal Sains dan Inovasi, III(2).

Irene Istiningsih Hadiprayitno. (2010). Defensive Enforcement: Human Rights in Indonesia. Hum Rights Rev, 11.

Ismail Asman dan Zaili Rusli. (2014). Penilaian Kinerja Organisasi Publik. Jurnal Kebijakan Publik, 5(1).

Mimin Dwi Hartono. (2012). Pendekatan Berbasis HAM dalam Penanganan Bencana: kasus erupsi gunung Merapi. Komisi Yudisial: Jurnal HAM, 8.

Nuriyanto. (2015). Membangun Budaya Hukum Pelayanan Publik untuk Mewujudkan Kesejahteraan Masyarakat. KPK: Jurnal Integritas, 1.

Ronny Hanitijo Soemitro. (1990). Metodologi Penelitian Hukum Dan Yurimetri. Jakarta: Ghalia Indonesia.

Saldi Isra. (2014). Peran Mahkamah Konstitusi dalam Penguatan Hak Asasi Manusia Di Indonesia. Jurnal Konstitusi, 11(3). 
Stanley Adi Prasetyo. (2012). Pemberian Jaminan Sosial dalam Hak Asasi Manusia. Komisi Yudisial: Jurnal HAM, 8.

Suparmin. (2014). Reorientasi Peran Polri dalam Penanganan Konflik Sosial dari Perspektif Penegakan Hukum. Jurnal Masalah-Masalah Hukum, 43(2). 